\title{
The anticipatory politics of dispossession in a Senegalese mining negotiation
}

\author{
Ashley Fent ${ }^{1}$ \\ Vassar College, USA
}

\begin{abstract}
The concept of accumulation by dispossession is often mobilized in political ecological and geographical literature, to explain the ways that capitalist accumulation depends on the violent and extra-economic seizure of land and resources. Yet dispossession is also mobilized as a fear about the future, as a way of articulating historical and non-capitalist motivations for land expropriation, and as an avenue for political action. Amid negotiations for a heavy mineral sands mine in the Casamance region of Senegal, narratives of dispossession circulated frequently, even though no mining had yet taken place. Drawing on ethnographic fieldwork and qualitative interviews, this article examines the contentious politics around the proposed mine, which mobilize multiple timescales. In this context, activists and village residents have engaged in an anticipatory politics that is influenced by past and present processes of land occupancy, environmental change, and state disinvestment, and is aimed at contesting potential dispossessions to come, making claims to resources, and securing a place in the imagined future. At the same time, state and corporate actors have engaged in their own anticipatory actions, through environmental impact assessments and other technologies of prediction that minimize, invalidate, or circumvent anti-dispossession movements. This article argues that experiences of and resistances to dispossession are mediated by the folding together of temporal frames and diverse displacements. In particular, it attends to anticipation as a key temporal mechanism through which dispossession is both enacted and contested. As such, it contributes to political ecology by combining materialist conceptions of dispossession and displacement with theorizations of anticipation and the future.
\end{abstract}

Keywords: accumulation by dispossession, anticipatory politics, mining, Senegal

\section{Résumé}

Le concept d'accumulation par dépossession est souvent mobilisé pour expliquer les façons dont l'accumulation capitaliste dépend de la saisie violente et extra-économique des terres et des ressources. Pourtant, la dépossession est également mobilisée comme une peur de l'avenir, comme un moyen d'articuler des motivations historiques et non capitalistes pour l'expropriation des terres. C'est aussi la base de l'action politique. Au milieu des négociations pour une mine de sables minéraux lourds dans la région de la Casamance au Sénégal, des récits de dépossession ont circulé fréquemment, même si aucune exploitation minière n'avait commencé. S'appuyant sur un travail de terrain ethnographique et des entretiens qualitatifs, cet article examine la politique litigieuse autour de la mine proposée, à plusieurs échelles de temps. Dans ce contexte, les militants et les habitants du village se sont engagés dans une politique d'anticipation qui est influencée par les processus passés et présents d'occupation des terres, de changement environnemental et de désinvestissement de l'État. Ils prévoient de contester la dépossession potentielle, en réclamant des ressources et en s'assurant une place dans le futur imaginé. L'État et les entreprises se sont engagés dans leurs propres actions d'anticipation, à travers des

\footnotetext{
${ }^{1}$ Dr. Ashley Fent, Postdoctoral Fellow, Earth Science and Geography Department, Vassar College. Email: afent "at" vassar.edu. Acknowledgments: Various stages of the research upon which this article is based was generously funded by the Fulbright-Hays Doctoral Dissertation Research Abroad program (grant number P022A140030-012), the Social Science Research Council International Dissertation Research Fellowship program, the Association of Pacific Coast Geographers, the Society of Woman Geographers, and the UCLA Graduate Division. I am grateful for research assistance provided by Abdullah Alhamirou Diatta. Though they go here unnamed, I also wish to thank many friends and residents of Niafarang, Kabadio, and nearby villages for their hospitality, generosity, and support in facilitating this research. The article has greatly benefited from the feedback of two anonymous reviewers and from Erik Kojola. All errors remain my own. This is the third article in Ashley Fent and Erik Kojola (eds.) 2020. "Political Ecologies of Time and Temporality in Resource Extraction", Special Section of the Journal of Political Ecology 27: 819-938.
} 
évaluations d'impact environnemental et d'autres technologies de prédiction qui minimisent, invalident ou contournent les mouvements anti-dépossession. L'article soutient que les expériences et les résistances à la dépossession se produisent dans la fusion de cadres temporels et de divers déplacements. En particulier, l'anticipation est un mécanisme temporel clé par lequel la dépossession est décrétée et contestée. L'article contribue à l'écologie politique en combinant des conceptions matérialistes de dépossession et de déplacement avec des théorisations de l'anticipation et du futur.

Mots-clés: Accumulation par dépossession, politique d'anticipation, exploitation minière, Sénégal

\section{Resumen}

El concepto de acumulación por desposesión es frecuentemente aplicado en literatura de geografía y ecología política para explicar las formas en que la acumulación capitalista depende de despojo violento y extraeconómico de la tierra y los recursos. Además, la desposesión es también aplicada a manera de temor al futuro, como una forma de articulación de motivaciones históricas y no capitalistas para la expropiación de la tierra, como una vía para la acción política. Entre negociaciones por una mina de arenas minerales pesadas en la región Casamance, en Senegal, las narrativas de desposesión circulan frecuentemente a pesar de que aún no hay actividad minera. Con base en trabajo de campo etnográfico y entrevistas cualitativas, este artículo examina la discusión política alrededor de la mina propuesta, la cual, aplica múltiples escalas temporales. En este contexto, activistas y residentes locales se han involucrado en una política anticipada influenciada por procesos actuales y pasados con respecto a ocupación de la tierra, cambio ambiental, desinversión del estado, y que apunta a oponerse a una potencial desposesión que se avecina, formulando la reivindicación de recursos y garantizando un lugar en el futuro imaginado. Al mismo tiempo, actores estatales y corporativos se han involucrado en sus propias acciones anticipadas a través de evaluaciones de impacto ambiental y otras tecnologías de predicción que minimizan, invalidan o eluden movimientos contra la desposesión. Este artículo argumenta que las experiencias en, y la resistencia a la disposición, están mediadas por el despliegue simultáneo de marcos temporales y desplazamientos diversos. En particular, se hace un enfoque en la anticipación como un importante mecanismo temporal a través del cual la disposición es tanto ejecutada, como confrontada. De este modo, se contribuye al campo de la ecología política al combinar nociones materialistas de disposición y desplazamiento, con teorización de la anticipación y el futuro.

Palabras clave: acumulación por desposesión, política anticipatoria, minería, Senegal

\section{Introduction}

One day in March 2016, Joseph ${ }^{2}$ explained his opposition to the Niafarang Project, a proposed heavy mineral sands (HMS) mine in the Casamance region of Senegal. He stood in his rice field - cultivated by his grandfather before him — which was adjacent to the proposed mine site. "I was born here", he said. "I don't want to be a stranger in another village." For Joseph, the unrealized mining project meant an end to his place in Niafarang. "Our lives depend on rice and palm wine", he continued. "And ever since [the mining company] took geological samples [in 2004], the salt has already been increasing in the fields." Here, Joseph moved seamlessly between past, present, and future; the proposed mining project was bound up in his ongoing experiences of salinization and environmental change, his fears of future displacement, and the history of rice cultivation within his family and in the village.

Although Joseph had not (yet) been dispossessed of his means of production, he experienced dispossession in a broader sense: as a fearful anticipation of a future in which he would be a "stranger", and through having already seen declines in rice production and abandonment of fields due to salt. As Joseph's statements demonstrate, experiences of dispossession are influenced by both natural and socio-economic forces and by understandings of the past, observations of the present, and prediction of the future. The ways that dispossession is understood and experienced in this case - as a potential future outcome from extractive capitalism, as sedimented upon previous experiences of dispossession, and as deeply related to the unpredictability of socio-ecological interactions - compels greater attention to anticipation within the literature on accumulation by dispossession (ABD) and its intersections with political ecology.

\footnotetext{
${ }^{2}$ In order to ensure confidentiality, all proper names of individuals in this article are pseudonyms.
} 
Discussions of $\mathrm{ABD}$ expose the extra-economic processes of violence, coercion, and seizure that underpin capitalist development, by freeing up both natural resources and labor for commodification (Glassman 2006; Harvey 2003; Hall 2013; Levien 2012). These approaches are insightful as historical lenses and interpretations, but how do they account for the proliferation of anti-dispossession politics (Levien 2013) that emerge in fear or anticipation of potential effects of unrealized development projects? Under what conditions do certain forms of anticipation - of future profits, or of future destruction-come to matter and to dominate the course of events?

During my ethnographic field research between 2014 and 2017 on the stalled negotiations for the Niafarang Project, loss of land and livelihood featured centrally in how people described and fought the project. The proposed mine's entanglements with past and ongoing processes of capitalist and extra-capitalist processes of dispossession encourages theoretical reconstruction of $\mathrm{ABD}$, with greater attention to a growing body of scholarship on anticipation, the future, and "the geographical grounds of fear and hope" (Sparke 2007: 338). I argue, first, that multiple pathways of engaging with dispossession emerged in the negotiations. Various actors asserted their predictions about future effects, based on differential experiences and interpretations of past and ongoing processes of dispossession. While state actors, the mining corporation, and local mining supporters attempted to enact a project that would certainly dispossess a small number of people of their land, activists and many local opponents predicted much wider dispossession through the mine's attendant and unplanned environmental effects. In turn, they feared that this potential future outcome - serving capital, albeit indirectly - would build upon and deepen historical and contemporary forms of non-capitalist displacement. This indicates that dispossession is mediated by the folding together of temporal frames and diverse displacements. As the second component of my argument, I show that these various actors engaged in anticipatory politics to navigate, minimize, or contest potential dispossessions to come, make claims to resources, and secure a place in the imagined future. By anticipatory politics, I refer to calculative and ad hoc practices through which different people try to secure future gains, and the ways in which the anticipatory actions of some negate those of others.

Following a review of the literatures on accumulation by dispossession and on anticipation, I trace in this article how anticipatory politics were used both to advance the proposed Niafarang Project and to disrupt it, in hopes of preventing the potential dispossession of land and resources. These diverse anticipatory politics aimed at securing beneficial future outcomes intersect with past and present experiences of marginalization, exploitation, and displacement. They also reflect power and inequality, as different actors attempt to exert their own anticipatory claims in competing and conflicting ways. Beyond the specificities of the Niafarang Project itself, I show that dispossession is an ongoing and contested process, which incorporates multiple temporalities and conflicting motivations of different groups of people.

\section{Anticipating accumulation by dispossession}

Accumulation by dispossession refers to the ongoing enclosure and capture of resources, in order to make them available for capitalist profit-making. ABD can occur through a variety of means: violently seizing land held by private owners, legally invalidating certain sets of land claims, or using market mechanisms to seize valuable assets, by pricing out the poorest populations (Glassman 2006; Harvey 2003). In David Harvey's conception, expanded reproduction produces overaccumulation crises that require spatial and territorial fixes, involving the freeing up of land and resources for capital investment (Harvey 2003). Diverse kinds of dispossession thus create an outlet for idle capital and allow capitalism to (temporarily) overcome its crisis tendencies. The theory of ABD suggests that dispossession is an ongoing and instrumental part of capitalist accumulation, rather than as a primitive or original stage, as Marx (1976 [1867]) theorized. It opens new frontiers for commodification through extra-economic means, such as law, coercion, or violence. This commodification may occur by: financializing nature or life itself(Fairhead, Leach and Scoones 2012; Goldman 2005; Orozco-Quintero and King 2018; Prudham 2007; Sullivan 2013); developing credit systems that produce new sources of returns on investment through debt (Keating, Rasmussen and Rishi 2010; Soederberg 2013); or developing mining projects that transform communities, ecologies, labor, and governance (Holden, Nadeau and Jacobson 2011; Maconachie 2014; Rousselin 2018). Creating these sources of investment often displaces those 
currently utilizing the resource (Beymer-Farris and Bassett 2012; Cavanagh 2018), separating them from privately or commonly owned means of production and compelling them sell their labor power.

In some ways, the Niafarang Project would seem to fit within such an understanding. A project led by a multinational company and aimed at the realization of profit from mineral reserves, it threatens to enclose resources held in common and exclude local actors as a result (Cavanagh 2018; Chen 2013; Ince 2014). The mine site to be progressively dredged from north to south is located on a sandy, tree-filled dune in between mangroves and the sea, to the west, and low-lying rain-fed rice fields and homes, to the east (see Figure 1). The project would require the removal of common property fruit trees on the dune, creating a new frontier for commodity production. Upon the completion of mining, the project promises to rehabilitate the site, allowing this land to be resold - likely for higher prices that would be unaffordable to most village residents. On its face, this situation appears to follow the narrative of ABD.

However, the project also departs from ABD, highlighting important critiques. First, the relationships between village residents, village chiefs, and the state in regard to patterns of land ownership have created and reproduced complex opportunities for dispossession and enrichment - not only by mining capitalists, but by local elites and state actors. The role of the state in capital accumulation has always been acknowledged within Marxist theories of primitive accumulation and ABD (Arrighi 2010; Harvey 2003; Marx 1976 [1867]), but the state also has its own motivations in dispossession that do not exclusively serve the imperatives of capital (Fairbairn 2013; Sneddon 2007). Domestic elites and national actors employ extra-economic means to secure land, sometimes for personal use (Fairbairn 2013), and land transfers may economically benefit a range of actors beyond simply private investors (Leitner and Sheppard 2018). Recent scholarship suggests that the state itself is comprised of, and constantly under construction by, a network of diverse (and sometimes conflicting) institutions and actors, which operates through transnational logics and networks of sovereignty (Bierschenk and Olivier de Sardan 2014; Chalfin 2004, 2010; Mountz 2010). Yet because state actors are often tasked with securing use rights for the benefit of foreign or domestic capitalists - or are themselves pursing capitalist interests - anti-dispossession political movements largely focus on the state as their targets (Levien 2013).

Second, unlike many cases of large-scale dispossessions (e.g. Forman and Kedar 2004; Gordon and Webber 2008; Levien 2012; Perreault 2013), the scale of the Niafarang Project is rather small. The proposed mine would cover an area of only 1.8 square kilometers. Using capital-intensive dry and wet zircon mining, the mine would consist of a gravitational separator and floating dredge that sit in a pond of 40 meters by 20 meters; the whole apparatus and pond would move south as deposits are mined. ${ }^{3}$ Legally, the project would require compensation of only seven landowners on the dune, including a Fulbe herder who has lived there since the 1980s, Mandinka and Jola migrants from other villages who own small "village hotels", and foreign absentee landowners who have entrusted their land and houses to local residents or residents from other villages while they are away. Newer landowners - largely foreign expatriates and temporary residents from Europeconstructed buildings after 2006, when an administrative order reportedly restricted further development of the dune amid mineral exploration.

Yet the fact that this is planned to be a small-scale mine with limited impacts does not mean that it will be. Mining corporations and the scientists they hire often dramatically underestimate potential hazards in order to get projects approved (Kirsch 2014). Due to their awareness of negative effects of mining elsewhere, opponents of the Niafarang Project highlight the possibility of extensive dispossession through unforeseen environmental effects. They have also consistently argued that the Niafarang Project is merely the first stage of mining concessions that could ultimately be granted across much of the Casamance coastline.

Finally, while dispossession from the mining project has not (yet) happened, people have opposed the project's potential displacements, articulating these through the lens of past and present experiences. Focusing on the logics of capital accumulation in post hoc analyses of enclosure or expropriation provides an understanding of how resources, people, and land are continually recreated as low-cost pathways for capital. However, this also grants capitalism a sense of coherence and totality, and neglects the complex and messy

\footnotetext{
${ }^{3}$ For comparison, the large Sabodala gold mine concession in eastern Senegal covered 20.2 square kilometers of land when the initial mining permit was signed in 2005, and was combined with another concession in 2015, totaling 245.64 square kilometers ("Sabodala Gold Operations" 2018).
} 
relationships between capitalist accumulation, the motivations of diverse actors (including the state), and historical, non-capitalist ecological and political processes that come to matter in contemporary dispossession politics.

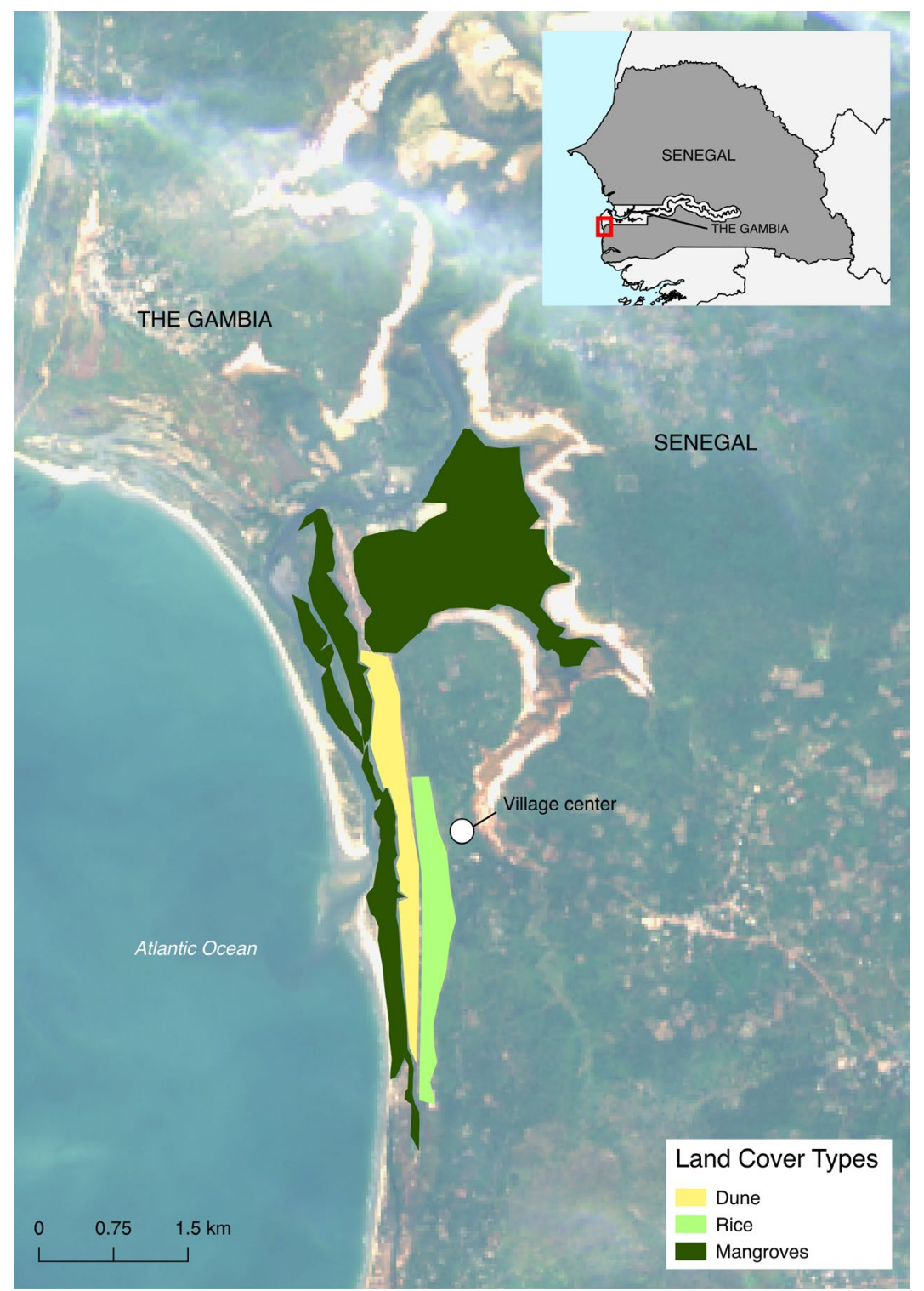

Figure 1: Land cover types in and around the proposed mine site (Map by author).

ABD and dispossession more broadly must be understood as influenced by the particular, contingent historical and geographical contexts in which they occur (Hart 2006). Dispossession and displacement may be caused by a variety of anthropogenic and natural factors (Perreault 2013) and by both capitalist and noncapitalist priorities in land seizure (Hall 2013). For instance, state-led land reform can result in not "dispossession of the land but a dispossession of autonomous control", by solidifying sovereign claims over territory (Lund 2011: 901). Similarly, "spatial dispossession", or the erosion of important sites of social, economic, and political life as a result of disinvestment, may occur through the loss of spaces for community 
building or labor organizing, the fracturing of social relations among residents, and damage to human bodies and physical landscapes (Smith 2015). Land and resources may be obtained through highly contested processes that combine consent with coercion and economic with extra-economic processes, exceeding the framework of dispossession (Leitner and Sheppard 2018). In some cases, enclosure may result not in evictions but in "in situ displacement" (Ince 2014). Experiences of dispossession and displacement therefore operate in a broader political economic field than is captured by attention to accumulation processes and direct seizures of property.

The materiality of the non-human world also creates circuitous pathways and diverse forms of displacement, amid geographically-specific networks of biophysical, social, economic, and political interactions (Sneddon 2007). As Tom Perreault (2013) suggests, "dispossession by accumulation" occurs in some mining projects, through the spatial extension of dispossession via sediment accretion, pollution, and unplanned disposal sites. These "accidental" forms of dispossession do not produce lands or resources that are useful to capitalism (Perreault 2013) - rather, they are externalities of capitalist seizures of resources elsewhere, in ways that nevertheless destroy the socio-ecological systems of communities. Dispossession thus occurs through many mechanisms and with many motivations (or lack thereof).

Given the politics involved in dispossession, people anticipate and resist potential future displacements that promise to create capitalist value while compounding historical inequalities and ongoing ecological loss. Resistance and opposition to ABD is not always progressive and may call upon localism or reactionary social forms (Harvey 2003). Reactions to dispossession have drawn on multiple kinds of logics, with some individuals embracing monetary compensation in exchange for land (Leitner and Sheppard 2018). Indeed, antidispossession politics are often not opposed to commodification of land or resources, per se, but to certain kinds of coercive commodification that accrue benefits for outsiders (Levien 2013).

To be effective, resistance movements necessarily use both spatial and temporal strategies. Antidispossession movements focus on the point of enclosure and on stopping what in some cases would be an immediate and total devastation of land and livelihoods (Levien 2013). These strategies also depend on what Stuart Kirsch (2014) terms the "politics of space", through networks of movements around the world and within countries, which can rapidly mobilize people and share information about threats. Additionally, people employ a "politics of time" (Kirsch 2014) to prevent projects before they begin, by producing delays and opportunities for mobilization. For instance, legal strategies may tie up negotiations in the court system, which may buy time for other kinds of oppositional strategies (Levien 2013). Anticipation is essential in these movements, as it allows activists to have information about planned projects and to engage early on in mobilizing for the defense of place against certain forms of capitalism. Here, the case of the Niafarang Project is a provocation to think through overlaps and gaps between materialist understandings of dispossession and displacement, and theorizations of anticipation and the future.

Anticipation and anticipatory action reflect a particular temporality in which time flows backward from the future, demanding a response in the present (Anderson 2010; Braun 2015; Granjou et al. 2017). The desire to manage and control the myriad uncertainties that characterize the contemporary world (Beck 1999) has led to "anticipatory governance", through which state actors and economic planners have developed strategies designed to predict or prevent a range of potential problems, such as the resource curse, natural hazards, peak oil, and continued effects from climate change (Adey and Anderson 2011; Anderson 2007; Pigott 2018; Szeman 2007; Weszkalnys 2014).

The capacity to anticipate - and to have one's anticipatory action matter - is unequally distributed. Morethan-human forms of anticipation, such as changes in plant biology or animal behavior in anticipation of changing weather patterns, are often denied agency and fail to generate issues of public interest (Adam and Groves 2004; Groves 2017). Furthermore, some people's predictive expertise or imaginations of the future win out, excluding alternative understandings and marginalizing other aspects of the socionatural world (Groves 2017). Some forms of anticipatory governance cause new kinds of dispossessions, such as through the expulsion, incarceration, or deportation of groups of people who are expected to pose future risks (Mitchell 2010). This illustrates the politics of anticipation, or questions about whose knowledge counts, who is granted the right to govern the future, and what resources become economically viable (Braun 2015; Granjou et al. 2017; Kama 2019). 
Although it is often the anticipatory activities of states, corporations, economists, and scientists that gain authority and dominance, ordinary people also experience the future in the present. A variety of conceptual frameworks illustrate individuals' experiences of being robbed of a meaningful place in the future; these include abjection, referring to exclusion from a promised developmental future (Ferguson 1999), nostalgia for the future (Piot 2010), and temporal dispossession, through which resource extraction and violence erode individuals' ability to experience time in predictable ways (Smith 2011). In some cases, resource users also deploy narratives of the past, including pre-colonial rights and structures, to counter threats of dispossession (Makori 2017). These approaches indicate various actors' emplacement in time, and their different visions of pasts and futures (Makori 2013). Through anticipation, diverse groups of people plan for, fear, and discuss possible or potential future events, while incorporating past experiences and historical narratives. It is thus important to consider the geographies of hope and fear that animate popular movements for "local repossession" in the face of ongoing threats of dispossession (Sparke 2007, 2013).

Focusing on urban contexts, AbdouMaliq Simone (2010) defines anticipation as "the art of staying one step ahead of what might come, of being prepared to make a move" (p. 62). Simone describes how ordinary people position themselves in the present to take advantage of potential future opportunities; their "anticipatory politics" do not involve prediction or planning in the same way as more formal modes of anticipation (Simone 2010). This view of anticipation as indeterminate and as a form of positioning complements political ecology work on anticipation, which at times presents actors' anticipatory practices as articulating coherent (yet competing) visions of what is to come. As Simone shows, anticipation is often unplanned and haphazard; it involves multiple actors trying, in different ways, to remain "a step ahead" in a highly uncertain world. In this article, I combine his idea of "anticipatory politics" with political ecologists' conceptions of anticipation as an unequal terrain of political and social action. In the case of the Niafarang Project, this allows for an understanding of how diverse actors-including state administrators, mining supporters, and anti-mine activists - sought to position themselves relative to differently imagined futures, to secure a place in these futures, and to have their anticipatory expertise prevail. I also show that these conflicting imaginaries of the future built upon and incorporated differing understandings of past relations of possession, dispossession, and loss.

\section{Background}

The politics of land ownership and land law have been important both in the mining controversy and in the conditions that gave rise to the separatist conflict in Casamance. The region historically and colloquially known as Casamance has experienced a low-intensity conflict between the MFDC and the Senegalese state since 1982, with the most recent peace accords signed in 2014. ${ }^{4}$ Although often portrayed as an ethnic conflict between the Jola-dominated areas of Casamance and the Wolof-dominated Senegalese state, the conflict is rooted in historical and political economic narratives, which occur to some extent along ethnic lines. Many in Casamance view their region as marginalized and exploited by Nordistes from Northern Senegal and cut off from the political and economic life of the rest of the country.

In Casamance, land expropriation contributed to the sentiments that informed the separatist conflict and broader calls for regional autonomy and self-determination (Cormier-Salem 1993; Hesseling 1994). The colonial leaders of French West Africa administered land in a way that bolstered claims to autochthony and existing religious authority (Boone 2007). By contrast, the independent Senegalese state passed the National Domain Law in 1964, which vested 95 per cent of the national territory in the hands of the state (to be administered through the councils of Rural Communities) and allowed for that land to be tenurable based on continuous productive use, rather than on claims to autochthony (Boone 2007; Mamdani 1996). This sometimes resulted in land transfers that dispossessed local groups that held unrecognized customary land tenure. Due to Casamance's fertile agricultural soil, verdant forests, and coastal villages, the region experienced numerous state expropriations for outside investments in groundnut agriculture, agro-industry, and tourist facilities, often to the chagrin of local people, who saw this as an invasion by Senegal (Boone 2007: 565). Additionally,

\footnotetext{
${ }^{4}$ Amid the conflict, this region was sub-divided in two administrative reorganizations. The result was three separate regions (none bearing the name "Casamance"): Ziguinchor, Sédhiou, and Kolda.
} 
Casamance was distinctive in that its land remained largely administered by appointed state officials, rather than by Rural Councils (Boone 2003: 125). While physically displacing some land users, Senegalese land law also enacted dispossession through the erasure of local autonomy and the establishment of sovereignty via territorial administration. In addition to the displacements caused by these land transfers, the idea of state-owned land was ideologically at odds with local understandings of land, particularly among Jola groups.

Mining prospection for the Niafarang Project commenced in 2004, with the project then owned by Carnegie PLC, based in Australia. After a series of mergers and acquisitions, the project has been fully owned by the Hong Kong- and Australia-based Astron Corporation Limited since 2008. It has been incorporated into Senegalese President Macky Sall's Emerging Senegal Program platform, which aims to develop mining and petroleum extraction as a means of national economic development, among other ambitious goals. The project proposes to extract HMS (zircon and titanium sands, including rutile, ilmenite, and leucoxene) from what is estimated to be a Probable Ore Reserve of 4.65 million tons, along a coastal dune. ${ }^{5}$ The project would begin in Niafarang, a small coastal village of 250 people in Casamance (see Figure 2).

The project has met with opposition by groups with diverse political viewpoints and ideologies. The locally-based, internationally-networked Committee Against Zircon Mining in Casamance, hereinafter "the Committee", has been actively organizing against the project since 2010. This group, led by residents of Niafarang and nearby villages, has organized marches and demonstrations against the mine, and has built support among foreign journalists, researchers, and lawyers, Senegalese politicians in the National Assembly, and the regional separatist Movement of Democratic Forces of Casamance (Mouvement des forces démocratiques de la Casamance, MFDC). All five branches of the MFDC oppose the mine, and some branches have taken a militant stance toward it, threatening to take up arms if it goes forward. By contrast, the Committee is a pacifist group. Both the Committee and the MFDC also have both collaborative and conflictual relationships with the village of Niafarang, as some village residents support one or both of these movements and others oppose them. The resistance of many Niafarang residents to the mining project is often less organized or politically-motivated than that of the Committee or the MFDC, and is more driven by fears of being displaced and by resentments about state neglect. The population of Niafarang and nearby villages includes a mix of wellestablished families who have lived in these villages for many generations, individuals from elsewhere in Casamance, Senegal, and West Africa, and European expats with permanent or winter homes in the villages.

In spite of de jure state ownership of the proposed mine site, the stakes of the mining project involve numerous competing claims to land by individuals, villages, and institutions. Although private titles cannot be granted, chiefs may grant allotments (affectations) based on the state's stipulations around use rights. In Niafarang and neighboring Mandinka villages, an influx of people from Europe or West Africa, elsewhere in Casamance, or elsewhere in Senegal seeking land has resulted in the selling of parcels of land on the coastal dune proposed for the mine site.

In interviews, state actors repeatedly stated a preference for negotiation rather than seizing the land by force, even though the mine site falls under the National Domain. They attributed this stance to their desire not to reignite the Casamance conflict. They also described dialogue and negotiation as reflecting Senegalese democratic political culture and commitments to dialogue (although in other contexts across the country, land has been expropriated with or without public acceptance).

The Niafarang Project remained in negotiation with communities from 2011 to 2017, when the Senegalese Ministry of Industry and Mines and Astron signed a Small Mine License. However, continued opposition by activists, residents, foreign and Senegalese researchers, and two members of the Senegalese National Assembly has contributed to additional delays and negotiations. At the time of writing, the project still has not begun construction.

\footnotetext{
${ }^{5} \mathrm{HMS}$ are used primarily as heat-resistant refractories in household appliances and nuclear reactors, and in the aerospace industry.
} 


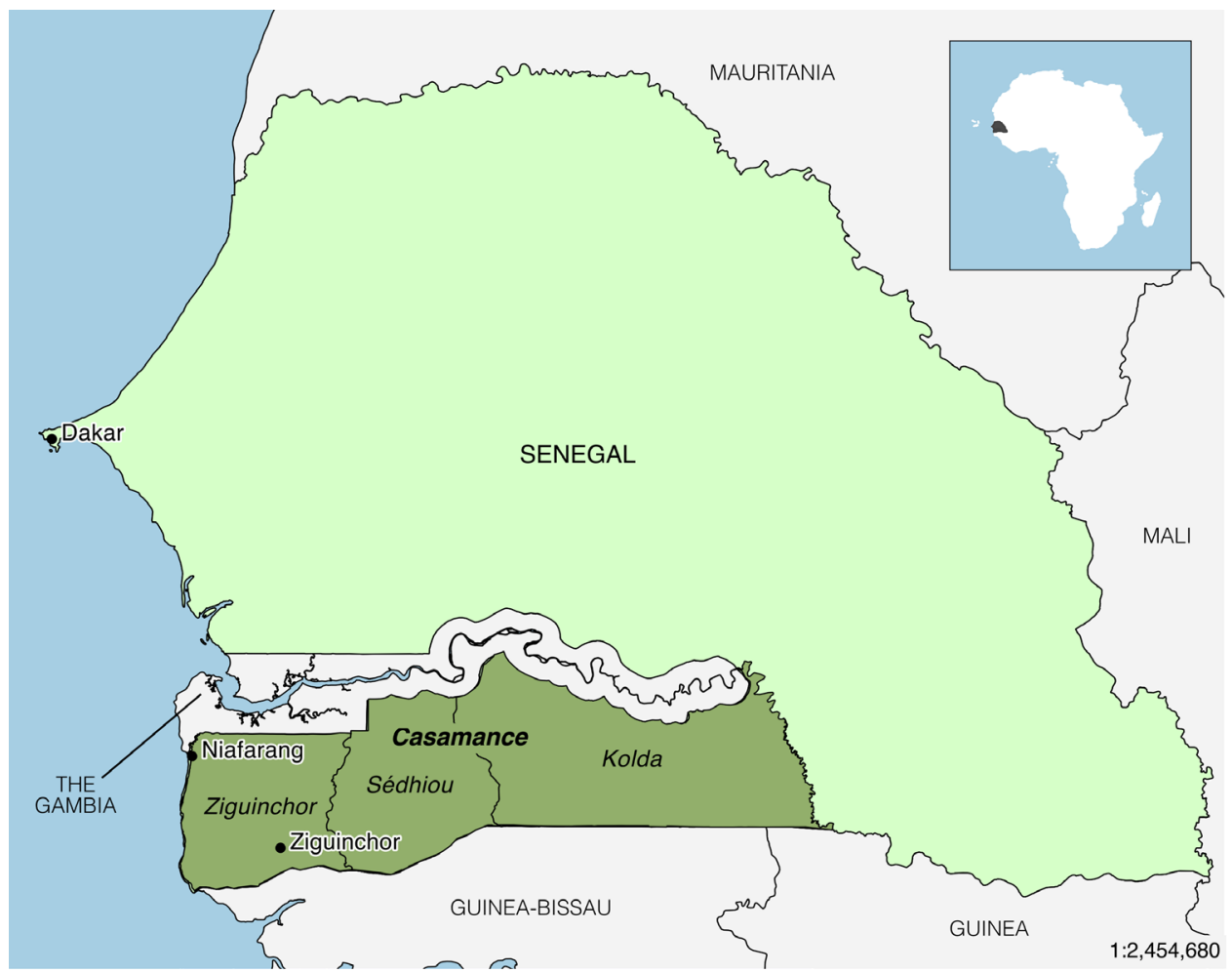

Figure 2: Location of Niafarang in the Casamance region of Senegal, in green (Map by author).

\section{Methodology}

This article is based on over 14 months of participant observation from 2014 to 2017, semi-structured interviews with individuals $(\mathrm{n}=87)$ and groups $(\mathrm{n}=12)$, and textual analysis of key legal texts and project documents, including the environmental impact study for the project. Participant observation entailed engaging in everyday life in Niafarang and nearby villages, having informal conversations with residents of these villages, and attending meetings specifically about the mining project. In the course of my research, I attended approximately ten meetings of the Committee, as well as two large public forums that included appointed state actors, elected local officials, NGO representatives, Committee members, and community members from diverse backgrounds (mostly men, and mostly people fluent or conversational in French). Attended by 40 to 50 people, these forums were dominated by attendees opposed to the mine, but at least one included a small number of village residents speaking in favor of the project. To gain a broader perspective on life in the villages, I attended one baptism ceremony, one work party among women, numerous agricultural work parties in multiple villages, conservation-related meetings, village meetings about the mining project, one church ceremony, numerous celebrations for Muslim holidays (such as Eid al-Fitr and Eid al-Adha), and one village festival. I selected and prioritized participation and observation based on those events to which I was invited (or which I felt were appropriate to ask to attend), those with relevance to the mining negotiations, and those which would maximize my connections with different groups of people. Selection of these activities was based on "theoretical sampling", which aims not for statistical representativeness but for the robustness of theoretical reconstruction, achieved by including differently positioned people, and engaging in constant comparison in the field (Burawoy 1998; Glaser and Strauss 1967).

Interviewees were similarly selected based on theoretical sampling. While my initial contacts were welleducated, male activists who were deeply familiar with and involved in opposing the mining project, I also pursued interviews with women, people who were less active in the opposition, and people who supported the mining project, as well as people who had only limited knowledge of it. Additionally, I conducted interviews 
with environmental consultants on the project and with state actors working at multiple levels of government, including elected local and national officials (e.g. mayors, deputy mayors, environmental directors within the mayor's office, and an elected representative in the National Assembly), regional and district-level appointed officials, and bureaucrats in the regional and national offices of the Ministry of Industry and Mines and the Ministry of the Environment and Sustainable Development. ${ }^{6}$ Sampling was purposive and was often arranged through existing networks and contacts. I solicited other interviews via official letters and requests-some of which were rejected. Because the mining company itself had little to no presence in the area or in Senegal, and did not respond to email requests for interviews, my understanding of their strategies is informed by what I observed from the perspectives of my interlocutors within Senegal.

My ethnographic fieldwork in villages was enabled by a growing network of activist interlocutors involved in the Committee. My early connections with the Committee and residents of certain villages precluded interviews with some people, even as these connections facilitated other interviews. I worked diligently to interview local supporters of the mine and to build trust, but in some cases, this proved impossible. As a consequence of my initial entry-point into the controversy, my understanding is based more strongly on the perspectives shared with me by activists and community members who were contesting the project, than with state actors or consultants - although I did conduct a number of interviews with these individuals and observed their interactions with community members whenever possible.

My positionality also matters in the sense that I am a white woman from the United States, with a degree of linguistic and cultural familiarity with Casamance and with Senegal that I have assiduously cultivated over time, but that nevertheless remains limited. While I could interview and converse in French or Wolof and often conducted interviews in other local languages with the assistance of a translator, I was unable to follow many everyday conversations in Mandinka or Kulonaay. This limited the depth of connections and conversations with some residents of the villages. Additionally, being a white foreigner with ample economic resources in some cases created opportunities - for example, to meet with influential state officials and to move easily between Dakar, Ziguinchor, and rural areas. In others, this generated distrust and suspicion that I might be a "spy" for the mining company or the United States government (a rumor that I unsuccessfully attempted to dispel). My positionality thus affected people's willingness to talk to me, the aspects of their experiences they shared with me, the ways they communicated with me, and the language barriers in those communications.

\section{Anticipatory politics: contesting dispossession, securing a place in the future}

Multiple pathways of engaging with dispossession emerged, as various actors in the negotiations attempted to impose their predictions about future effects, based on differential experiences and interpretations of past and ongoing processes of displacement. State actors, environmental consultants, mining supporters, antimine activists, and ordinary people have all engaged in anticipatory politics - with different motivations and different techniques - in order to navigate, minimize, or contest potential dispossessions to come and to establish claims to the future. The mining company and the Senegalese state used anticipatory techniques, such as environmental impact assessment, to render the mine and its effects minimal and inconsequential. By contrast, activists and local mine opponents advanced their own predictions of displacement, their experiences of environmental loss, and their perceptions of state neglect during public forums. This effectively (but temporarily) stalled the mining project. In response, local mine supporters and state actors drew upon historical narratives of land occupation and dispossession in order to assert the rights of a small group of people to make decisions about Niafarang's land, in anticipation of future payouts. Confronting uncertain environmental futures regarding the mine - and more generally — activists and Niafarang residents attempted to stake claims and resist potential future dispossession from the mining project through tree planting campaigns, establishing precarious rights to compensation.

\footnotetext{
${ }^{6}$ Formal interviews included village chiefs ( $\mathrm{n}=5$, all older men); activists ( $\mathrm{n}=8$, all men); environmental consultants for the mining company $(n=2$, men); bureaucrats and appointed state officials $(n=13$, mostly men); elected local officials $(n=4$, all men); members of the MFDC ( $\mathrm{n}=4$, all men); and local residents not directly or actively involved in the Committee, including women $(n=16)$ and men $(n=22)$. Of this latter group, only two people expressed unequivocal support for the mine.
} 


\section{Minimal impact: contested predictions of the future}

Ordinary people's anxieties about dispossession in and around Niafarang often focused on the effects that the mining project could have on the ecosystem. As one man described in a public forum in May 2015, "this is a very sensitive area, where it's not allowed to extract beach sand because it exacerbates sea level rise, and yet they're going to extract a million tons of heavy sands in an area that serves as a barrier against salt and the sea." Many village residents believed that the heavy mineral sands exerted a stabilizing force on the coast, as a substitute for the rocky coastal substrates elsewhere in northern Senegal. Accordingly, they were concerned that removal of these heavy mineral sands would make the remaining lighter quartz sands more susceptible to erosion and to sanding over of adjacent mangroves. This, in turn, was anticipated to contribute to the sea's encroachment into village space.

Yet the Environmental and Social Impact Study (Étude d'impact environnemental et social, EIES) conducted for the project found that effects on broader ecosystem processes would be minimal. As mandated by the Senegalese Environmental Code, Carnegie hired a Dakar-based environmental consulting firm to conduct the EIES, which was completed in 2010 and revised in 2011. The EIES offered scientific risk and impact assessments for discrete and compartmentalized aspects of the environment, and predicted that impacts on land and water resources would be minimal - echoing broader patterns in how environmental assessments function through simplification (Bedi 2013; Kirsch 2014). Consultants for the mining company and some state actors stressed the mine's minimal impacts and the small number of individuals who would be directly displaced by the mine. This portrayed it as innocuous and small-scale, invalidating suggestions of more widespread ecological issues that could dispossess many more people beyond the mine site itself. In this view, the benefits from mining - in the form of "development"-would far outweigh minor inconveniences. One environmental consultant for the mining company expressed his frustration about the negotiations, favorably contrasting Astron with other failed investments and arguing that the company had many plans for local development projects, including reinvesting the equivalent of $\$ 20,000$ per month back into the community (interview, Sept. 11, 2014). In his view, these much-needed investments were being blocked because of negligible environmental risks for a few landowners. The EIES allowed for unpredicted or unintentional displacements in the future by negating their possibility in the present.

According to the Senegalese Environmental Code, however, environmental assessments must be presented and approved during a public forum. As critiques of environmental assessments in other mining controversies around the world have suggested, these assessments and their associated public forums are often a strategy for canalizing and depoliticizing dissent, leaving some kinds of claims outside of the frame allowed by public hearings (Hébert 2016; Kirsch 2014; Li 2015; Zalik 2015). They are important tools through which states can legitimize environmentally destructive projects that are anticipated to create future revenues, while simultaneously appearing to maintain commitments to sustainability. In Senegal, this requirement for public approval may be met through limited awareness-raising or publicity in advance, leading to low attendance. In some cases, reports suggest that broader communities have not been consulted about risks of environmental damage or potential displacement, leading to protests and complaints of inadequate compensation or benefits once construction or operations begin ("Projet Grande Côte" 2018; "Sabodala Gold Operations" 2018). ${ }^{7}$ Furthermore, the consultation process has been criticized for narrowly confining public participation and consent to the environmental evaluation phase of mining negotiations, which occurs after exploratory research — and, in some cases, contested mining operations on an adjacent concession - have already taken place (Amnesty International 2014; d'Avignon 2018: 124). In the Niafarang Project negotiations, the Committee's early organizing work and campaigns led hundreds of people to attend the first official public forum in 2011. This pre-emptive action reflected existing connections between well-educated community members, environmentalists and political groups operating at the national and regional levels, and expats who

\footnotetext{
${ }^{7}$ For example, the environmental impact study for the Sabodala gold mining concession in eastern Senegal was completed in 2007, two years after exploratory drilling commenced (Niang 2012: 52; "Sabodala Gold Operations" 2018). Additionally, amid ongoing protests about low employment and few local benefits from the mine (and the exclusion of artisanal miners from sites they previously used), local representatives and residents boycotted meetings designed to approve the environmental and social impact assessment for another "satellite" mine that would be linked to Sabodala (d'Avignon 2018: 124).
} 
shared information on successful campaigns (interview, Aug. 26, 2014). At the public forum, activists and community members criticized the findings of the study, which had been distributed to them in hard and electronic copy in advance. Due to their rejection of the study, an additional public forum was organized in 2014. The audience once again rejected the study and refused to consent to the mining project.

In these forums and in other conversations about the mining project, village residents offered their own predictions of environmental risks, based on changes occurring in the present. Village residents expressed concerns about unpredictable interactions between the water cycle, coastal geomorphology, and agricultural production. Wells in the northern and eastern sections of the village have been abandoned due to salinity, with the main remaining potable wells existing on the dune and in the center of the village, where most women now go to collect water. There are many reasons for salinization, including decreased precipitation due to climate change and increased saltwater intrusion in coastal aquifers. Salinization has led to the abandonment of many rice fields and the inability of even the most salt-tolerant mangrove species to grow in the channels of brackish water that rise with the tides. These processes occurred independently of the mining venture, but the dispossessions they have already caused for rice fields, common property mangroves, and privately-held land along the coast made residents wary of the ways in which the mine could aggravate ongoing environmental issues. Further dispossession of land and water resources could also impact gendered responsibilities for social reproduction, including water provisioning, as has occurred in other cases (Fernandez 2018). Experiences of ongoing coastal environmental change thus informed views of the mine's potential impacts on both land and water. Local understandings of the proposed mine site as deeply connected to the rest of the socio-ecosystem contrasted with the EIES' dismissive attitude toward discrete environmental risks.

In response to past and anticipated future dispossessions, village residents engaged in an anticipatory politics of debate about the EIES. They mobilized in advance of public forums, highlighting discrepancies between the EIES and people's daily lived experiences of environmental change. This process decentered the predictive expertise of consultants hired by the company, by generating village residents' own predictions and entering these into the debate.

Members of the Committee frequently expressed concern and frustration that official written reports of their refusals of the EIES at public forums had never been generated by state actors. This complaint occurred in one public forum I witnessed, in which activists demanded the nonexistent report from the district administrator who was then present and had been involved in the mining negotiations. Members of the Committee feared that not formally registering the public's rejection of the project left the process open to further negotiation and circumvention - as did indeed occur, discussed in the following section.

In spite of some state and corporate actors' attempts to circumvent the process, the debate about the EIES allowed for the postponement and delay of the project for a number of years, as it was stalled at the public approval stage. Activists in the Committee demanded an independent and objective study that also incorporated and acknowledged local and place-specific knowledge. They felt that the EIES, conducted by Dakar-based scientists, had underestimated the ecological sensitivity of the site and had not considered the complex ecosystem processes that local actors experienced and observed. Furthermore, they raised concerns that the environmental consultants were simultaneously working for the mining company and felt that because of this conflict of interest, the assessment was heavily biased.

Sympathetic state actors lent their support to the Committee's challenges to the EIES and the approval process. At the district-level, some appointed and elected officials agreed with the local population that there had been a conflict of interest. For example, when I interviewed an administrator who was closely involved in the negotiations and ultimately ended up being a supportive ally (according to members of the Committee), he criticized the approach of "the Astron guy":

AF: Whom do you mean when you refer to the "Astron guy"?

Administrator: I mean [name withheld], who is at once the consultant as well as the company representative. (interview, Jan. 25, 2016) 
In addition to this official's criticisms of the EIES process, it was rumored among Committee members that another state official who had been appointed to the area had been sent elsewhere in the country as a consequence of his outspokenness against the mining project. At the same time, two politicians elected to the National Assembly worked with the Committee to debate the EIES, including on national television and in press conferences. That some state actors were actively working to challenge the study and the mining project, while others were diligently pursuing its acceptance, illustrates the partitive nature of the state and the enactment of its coherence through everyday behavior and institutionalized norms.

As of early 2018, pressure from various actors - including the Committee, foreign allies and scholars, and national politicians - to conduct a new EIES reputedly resulted in the Ministry of Industry and Mines agreeing to conduct a new study. However, this was only a partial success; if a more rigorous study were to be conducted and were to find similarly favorable results, this could further legitimize the project and move toward implementation, leaving less room to challenge the project.

Amid the negotiations, then, state and corporate actors were forced by the norms of governmental procedure to anticipate and plan for likely environmental effects from the mine, which they expected to be of minimal impact and of spatially limited extent. However, community members and activists anticipated more severe impacts that could extend far beyond the mine site itself, potentially dispossessing them of rice fields and water supplies. They articulated these predictions in public forums, and connected with well-positioned state and non-state actors in order to delay the project until what they felt would be a more reliable environmental assessment could be conducted. This succeeded in delaying the project, but left open possibilities for circumvention and project approval.

\section{Getting signatures: contested mobilizations of the past}

On a Friday in 2016, I sat with a group of elders as they waited for the afternoon prayer. It was a particularly tense time in the mining negotiations, after certain state actors and the environmental consultant had reportedly convinced a small group of men in this village, located a few miles away from Niafarang, to sign off on a Memorandum of Understanding approving the mine. As one of the elders recounted, his village's founders had originally wanted to settle in what is now Niafarang, but they realized that a coastal village would have nowhere to expand and instead they retreated inland. With his finger, he drew a circle in the sand, representing an island near Niafarang. He then drew a line across it. "We are the ones who gave the land title to [the owner of a quaint hotel on that island]." He drew another line. "We can give you this parcel, if you want", he told me, laughing. "All of that land, it's our land."

State actors and a handful of local mine supporters articulated "first-comer" claims and narrated the history of local land occupation in ways that were conducive to a new round of capitalist accumulation, in the form of the mining project. Competing histories of original dispossession (and therefore "rightful" land occupation) pitted villages against each other; amid contentious debates about the impending mining project, village residents could be heard vociferously arguing about the historical past, and about whether the Jola or the Mandinka had first vanquished the indigenous Bainuk. As Carola Lentz (2013: 19) suggests, first-comer narratives "are inherently contradictory because they combine notions of mobility (having come first implies having immigrated from somewhere) with the apparently natural legitimacy of being autochthonous (having been there before the arrival of others)." Amid the Niafarang Project mining negotiations, contested first-comer claims mattered because they established rights to land and rights to promised future benefits from mining.

The village of Niafarang was formed through waves of conquest, settlement, and pre-capitalist dispossession. These multiple dispossessions and conquests-many of which occurred prior to French colonization - did not serve capitalist accumulation, but rather achieved political and religious dominance, and economies based on tribute. In the sixteenth and seventeenth centuries, Kaabu - a powerful Mande vassal state of the Mali Empire - conquered the Banyun states of the Bainuk and installed Mande leaders to rule over Bakspeaking Kujamaat (Jola) in the region (Barry 1988). According to oral histories recounted to me, the Mandinka who fought for Kaabu in conquering missions against the Bainuk and Bak speakers were granted a concession of land; they were to settle where they found "water as far as the eye can see." Arriving at the Atlantic Ocean, they established a village a few kilometers from the present-day village of Niafarang. In the nineteenth century, 
amid the wars between Islamized Mande marabouts ${ }^{8}$ and animist Soninke Mande kings, Bak speakers still living in the area who refused to convert fled into the Karon Islands to the south of present-day Niafarang. Over the following centuries, Kalorn (Jola $)^{9}$ seasonal laborers came up from the Karon Islands to tap palm wine and collect palm seeds. Eventually, some of these laborers obtained permission to settle permanently in the coastal village, which they named Niafarang. The two villages' chiefs agreed to share the responsibilities of granting land titles; eventually, they divided parcels for each to administer and control.

These non-capitalist dispossessions became salient to contemporary capitalist accumulation because patterns of historical land ownership and narratives about these patterns enacted claims to land and decisionmaking, in the context of new potential for realizing future mineral resource value. In 2015, as part of the attempt to get the mine approved by local populations, local state actors and a Dakar-based consultant for the mining company engaged in closed-door meetings with male elders in the Mandinka village, reportedly offering them future payments and benefits. Two activists and a handful of concerned residents in Niafarang recounted to me that they had caught wind of one of these meetings and had tried to attend, but were turned away. The result was the drafting of a Memorandum of Understanding (MoU) that outlined local demands and was signed by the mining company as well as the village chief. This MoU simultaneously asserted and relinquished to the company the Mandinka village's claim to land in Niafarang. In legitimizing this, male elders of the Mandinka village cited their first-comer status as granting them the ability to consent to the project in the present.

As a result of the mining negotiations and the "divide and conquer" tactics employed by state and corporate actors, ethnic and historical conflicts resurfaced among the villages, in spite of numerous cooperative and collaborative relationships that have long connected them. Residents of the Mandinka village described Niafarang as a "satellite" village, and its people as their "guests." This characterization relied on Mandinka firstcomer claims, and positioned this village as the rightful owner of the land. For those supportive of the mining project, this would allow them to benefit materially and economically from an eventual mining concession. Even those who were opposed to the mining project in the Mandinka village argued that they were the rightful owners of Niafarang's land, and used this to justify their opposition to a potentially destructive extractive project.

By contrast, the Kalorn described themselves as the original inhabitants of Casamance, who were expelled and pushed out. They argued that Niafarang and its environs were part of their traditional territory, which stretched from the islands to present-day Banjul, in The Gambia, and based this claim on Jola conquests of the Bainuk. ${ }^{10}$ Many in Niafarang felt that their Mandinka neighbors' support of the mining project emerged from jealousy, because they had settled inland and had, by this geographic accident, forfeited later benefits from coastal eco-tourism.

State administrators appointed to the region and district largely adopted the historical interpretation articulated by the Mandinka. During one interview, an administrator involved in the negotiations described Niafarang to me as a "satellite" village or a neighborhood of the Mandinka village, stating: "There's the [Mandinka village], and its other satellite villages... We want unity around the [Mandinka village]" (interview, Mar. 7, 2016). As a result, and in juxtaposition to the user rights ostensibly protected by Senegalese land law, state actors reinforced the rights of the "autochthonous" or "indigenous" population (les autochthones) understood in a very particular and peculiar way that served the interests of getting the mining project approved. Namely, this understanding of autochthony elided the fact that the Bainuk were widely held to be autochthonous to the region, but were conquered and assimilated by both Mandinka and Bak-speaking groups. Instead, state

\footnotetext{
${ }^{8}$ The term marabout refers to Muslim clerics.

${ }^{9}$ The Kalorn are also known as Jola-Karon or Karoninka. They are speakers of Kulonaay, a language in the Bak language family.

10 This latter argument is supported by Steven Thomson's account of the nineteenth-century maraboutic wars led by Foday Kaba and Foday Sylla against the animist Soninke (Mande) king of the Combo (Thomson 2011). The Mandinka played a strong role in converting the Kujamaat to Islam, a process in which cultural processes and cultivation shifted to resemble hierarchical, segregated Mandinka forms of social organization rather than more egalitarian systems characteristic of the "Jola" (Kujamaat, Kalorn, and Jola-Kassa, all of whom speak what are considered dialects of a similar language) (Linares 1992).
} 
actors managing the negotiations deemed the Mandinka villages, which were more mixed in their sentiment about the project, able to legitimately speak for Niafarang, based on first-comer claims established in previous waves of dispossession. This understanding marginalized Niafarang residents and foreign landowners, while legitimizing both the land claims of certain Mandinka elders favorable to the project and the state's closed-door negotiating tactics.

Historical narratives of land occupation and past dispossessions were thus instrumental in this new phase of capitalist accumulation, even as they did not directly lead to it. Their retellings and contemporary assertion allowed certain local actors to make claims to land, in anticipation of future payouts. Similarly, state and corporate actors seized upon and reinforced particular historical interpretations of land occupation, in order to legitimize the decision-making of a small group of people. This effectively robbed Niafarang residents of their rights to make meaningful decisions about their land, thereby paving the way for actual dispossession in the future. These anticipatory politics were further complicated by the active engagement by Niafarang residents and Committee members in repudiating these historical interpretations and the undemocratic process of securing project approval.

\section{Neglect and dis-investment: demanding and securing a place in the future}

While Joseph attributed the salt rising in his fields to Carnegie's exploratory sampling, other village residents felt that the mining project would compound and exacerbate processes of coastal environmental change that predated and occurred independently of the mining company's exploration of reserves, but that nevertheless illustrated long-standing state neglect. Their fears about the effects of mining were shaped by ongoing experiences of eroding coastlines and salinized fields, and by perceptions of state disinvestment in the region.

On one trip to the beach, a Niafarang resident whom I refer to here as Dookulaabaa pointed to a sand bar around 150 meters away, across a channel of water, where he used to harvest palm wine and oil. He commented on the changes he had witnessed as the sea carved into village land:

My father crossed at the other side to harvest palm wine, over there after the river... Now, there are no more palm trees over there, because all of them have fallen into the sea. Now no one can collect palm wine there, because there's nothing, as a result of erosion. Before, at the start, my father had his nursery there. There were lots of young palm trees. There was even a small path where you could cross. But now, all that is over. Everything is gone.

Dookulaabaa's narration illuminates the depth of loss that is already felt in Niafarang as a result of coastal erosion. Dookulaabaa viewed the mining project as occurring atop this local history of loss, destruction, and willful state neglect. "They did the environmental impact study without talking to us", he told me. "I'm from Boune, and I'll go back there if they mine the zircon here. But my father left there before I was born. If I go back, I'll know no one, I'll be a stranger there." This illustrates prevalent fears, frequently expressed to me by both male and female residents of Niafarang, that the proposed mine would build atop this destruction.

Local residents often narrated the state with reference to these coastal dynamics and their impact on village life. For example, on another occasion, Dookulaabaa complained, "The sea is eroding the coastline. And because we're near the [Gambian] border, we've been forgotten... The state has done nothing for us here." His description echoed broader perceptions of the state that were communicated to me in interviews, as well as uttered in public forums and meetings. Activists and residents often contrasted their experiences of state neglect with state actors' sudden interest in engaging in discussion and negotiation with village residents about the potentially destructive mining project. In conversations, interviews, and public forums, residents and activists expressed concerns that the mine would destabilize the dune to such an extent that low-lying rice fields and homes to the east would be completely inundated. As one Niafarang man told me, "The sea will crush us" if the mine were to begin (interview, Mar. 8, 2016). A member of the Committee also expressed similar fears of inundation from the mine and reflected on what he felt was a contradictory governmental approach to coastal management: 
The authorities came, we brought them all the way to the sites. We showed them that part of the sea. And the President of the Republic, Macky Sall, ... who is in the process of fighting to try to protect other coasts, ... that Macky Sall who is in the process of spending billions to get people out of floods, that Macky Sall who gets up late at night to go meet with populations in flooded areas, that Macky Sall shouldn't want billions just to flood us. What did we ever do to him? (interview, Aug. 26, 2014)

The mining project had enabled the state to see and acknowledge Niafarang, but as a site of investment in the nation's future, rather than as a place in need of protection.

The mining project, as a proposed form of capital accumulation, built upon and intersected with histories of dispossession without accumulation. In this case, dispossession without accumulation inverts the formulation of "dispossession by accumulation" (Perreault 2013), in which the deposition of toxic sediments from mining dispossess people without any corresponding seizure of their land or conversion of that land to productive use. In Niafarang, coastal erosion has led to the loss of habitable land, buildings, and potable water resources, without adequate replenishment of the coast through sand deposition patterns. The land that has been eroded or salinized, and thereby rendered useless for agricultural production, has not been productive of value in a direct sense. Instead, these past and ongoing experiences conditioned how people understood relationships between sands, the sea, and economic life, and how they narrated this loss as the result of state neglect and willful inaction. As areas of remaining land in Niafarang were slated for expropriation and external profit creation through extraction, local people viewed the mining project as allowing people in faraway places to benefit from the further destruction of their village and their land. The promise of capital accumulation (for the mining company and the state) thus compounded ongoing resentments about dispossession from environmental change and the government's neglect of the village.

In response, village residents demanded alternative investments by the state to increase economic activity while also securing their land. During a public forum in May 2015, one man approached the state actors who were present and declared that President Sall's development program, the Emerging Senegal Program, should instead be the "Emergent Casamance Program." Later in the meeting, another man stated, "There are plenty of activities that companies could invest millions in, without causing more environmental problems." Residents of Niafarang in particular often highlighted their desire for a seawall and anti-salt dams ${ }^{11}$ to restore and protect their rice fields. As one Niafarang man said during a village meeting in July 2015, "we want investments that will hold back the sea, not speed up its advance." This demand for a seawall also came up and was rejected by the mining company during the negotiations, according to separate interviews with a bureaucrat and with two men involved in the secretive negotiations for the Memorandum of Understanding. As village residents sought to anticipate the ecological and economic futures of development in the area, they articulated demands that were designed not only to avoid dispossession by the mining project, but to gain governmental and outside investments in securing their land and interests, in the context of ongoing ecological change.

They also made their own investments in the future, by staking new claims on the dune in the context of the mining negotiations. In August 2015, thirty-eight men and women from Niafarang had convened to discuss the mining project under the large kapok tree that marked the main square. Near the end of the meeting, one man began explaining to me the need to "develop" and defend the dune:

The land is sacred. God gave us this land. ... The Jola [ethnic group] do not sell land. Land is the reason we hid in the bush [referring to the rebellion of the MFDC], and when there was war elsewhere, we came westward because of this land. So we've mobilized to develop the dune, and we've organized groups. It's hard to defend ourselves against the state, but if we plant trees, we can defend the dune. We have to develop that land as quickly as possible.

\footnotetext{
${ }^{11}$ Anti-salt dams were the subject of considerable debate and discussion in Senegal in the 1980s, and a number of them were constructed in Casamance (Manga 2014). Although they generally allow for reclamation of salinized soils for rice production, they are sometimes accompanied by adverse impacts on water sources and fish populations (Le Reste 1988; Loyer et al. 1986).
} 
For him, planting trees was a means of "defense" against the mining company and the state, by establishing value in the land.

During fieldwork, many people similarly noted that in order to combat the project, they needed to "develop the dune", by planting tree seedlings and in engaging in land improvements. In 2017, as mining negotiations heated up, village residents planted seedlings across the dune, marking these with sticks. Initially, I found this effort perplexing, and viewed it as futile in combatting a foreign-owned and state-supported mining project. But the idea of "developing the dune" was fundamentally about producing alternative forms of future value in land, and using these alternatives as leverage against the state.

Tree planting was an anticipatory act of possession, set in opposition to dispossession. Scholars of forestry in West Africa and beyond have noted the complex systems of ownership that are conferred through tree planting and harvesting (Ribot and Peluso, 2003; Rocheleau and Edmunds, 1997; Schroeder, 1999b). Planting trees establishes claims to ecological assemblages, granting access or property rights that overlap with other forms of land tenure. Particularly in the context of rapid coastal environmental change, tree planting has also been promoted by various NGOs and state institutions as a way of stabilizing the coastline and mitigating erosion. Planting trees as an act of anticipation thus sought to intervene in the future, by securing claims to the mine site in the present and by physically contributing to the stability of the ecosystem.

Tree planting not only enacted Niafarang's claims to its own land, but also moved to establish a basis for additional compensation, were the project to go forward. In 2006, the Senegalese state had reputedly issued a moratorium against any new construction or improvements on the dune, in anticipation of the pending mine. ${ }^{12}$ This injunction was designed to prevent people from claiming higher compensation values on land they already owned, and to prevent additional people from purchasing and building on plots. In this context, tree planting was a relatively low-cost form of investment that could be attempted in order to assert rights and claims. In theory, economically useful tree species are factored into compensation determinations, according to Senegalese officials' own interpretations of the treatment of Project Affected People. Therefore, the tree saplings could potentially be counted as land improvements, increasing the value of the land and the amount of compensation, in the event of future dispossession.

Finally, tree planting was part of broader efforts to establish alternative forms of development that were seen as more consistent with the ecological basis of village life. Tree planting also came up during a meeting in Niafarang in 2016 to discuss "counter-projects" that could operate as alternatives to the mine. As part of a proposed counter-project to declare Niafarang an "eco-village", a number of attendees suggested planting cashew trees. There seemed to be a consensus, as each subsequent speaker also referred to cashews. But then a French man in attendance interjected: "I think you should be cautious about planting cashew trees... They require a lot of water and damage the soil." Others considered this and began discussing additional species that could be planted. A man from Niafarang suggested teak and coconut palms - both economically useful species, the first of which has been widely depleted because of cross-border hardwood trade with The Gambia. As the attendees conversed, they envisioned "alternative" and non-extractive relationships of humans to the environment. These anticipatory actions around trees and "developing the dune"-by enacting new temporal processes of tree growth on a dune seen by the state as otherwise lifeless and expendable - represented village residents' attempt to secure their place in the imagined future.

\section{Conclusion}

Examining fears, experiences, and contestations of dispossession in the Niafarang Project raises broader questions about the temporality and anticipation of dispossession. I have traced the contours of an anticipatory politics of dispossession, showing how these politics build upon histories and present experiences of other forms of displacement. Resistance to the mining project was largely effective for a number of years, due to a widespread mobilization of people anticipating future damage, connecting with supportive actors at multiple scales, and making strategic investments in and demands for the future.

\footnotetext{
${ }^{12}$ Although a number of my activist interlocutors referred to this moratorium, neither they nor I could find any official record of it.
} 
However, anticipation in itself cannot prevent dispossession. Anticipation is a particular temporal approach, common to both rule and resistance in the contemporary world, that involves competing and contradictory forms of predictive expertise, knowledge, and preventive action. As such, state and corporate actors also engage in their own anticipatory practices, employing formalized methods of prediction and planning (such as environmental impact assessment or price forecasting). In this case, residents' anticipatory actions have been subverted and circumvented by the incorporation of historicist claims to land into the negotiations, and they are subject to domination if a subsequent environmental study also finds broader risks to land and water to be minimal. Moreover, if and when these resources become a priority for the state, or if other incentive structures change, it is possible that land will be expropriated, and the mine site brought into production despite this opposition movement. This, indeed, is the central insight of theories of ABD - that extra-economic forms of force and violence may be employed by states to open up land for capital. As such, the successes of the opposition remain extremely precarious.

At the same time, theories of ABD do not fully acknowledge the potential of anticipatory movements to prevent dispossession, the constructedness of the state, nor the multiple pathways through which past, present, and future forms of displacement may become productive for capital. Beyond the specifics of the Niafarang Project, this analysis encourages a view of ABD that is rooted in historical dynamics as well as dispositions toward future development, and that considers multiple social, economic, and ecological factors. Amid the anticipatory politics of dispossession, the possibilities of loss and displacement are paradoxically both deeply felt and difficult to predict in advance.

\section{References}

Adam, B. and C. Groves. 2007. Future matters: action, knowledge, ethics. Leiden: Brill.

Adey, P. and B. Anderson. 2011. Anticipation, materiality, event: the Icelandic ash cloud disruption and the security of mobility. Mobilities 6(1): 11-20.

Amnesty International. 2014. Mining and human rights in Senegal: closing the gaps in protection. London: Amnesty International.

Anderson, B. 2007. Hope for nanotechnology: anticipatory knowledge and the governance of affect. Area 39(2): $156-165$.

Anderson, B. 2010. Security and the future: anticipating the event of terror. Geoforum 41(2): 227-235.

Arrighi, G. 2010. The long twentieth century: money, power and the origins of our times. New York: Verso.

Barry, B. 1988. Senegambia and the Atlantic slave trade. Cambridge: Cambridge University Press.

Beck, U. 1999. World risk society. Cambridge: Polity Press.

Bedi, H.P. 2013. Environmental mis-assessment, development and mining in Orissa, India. Development and Change 44(1): 101-123.

Bierschenk, T. and J.-P. Olivier de Sardan. 2014. Studying the dynamics of African bureaucracies: an introduction to states at work. In Bierschenk, T. and J.-P. Olivier de Sardan (eds.). States at work: dynamics of African bureaucracies. Leiden: Brill. Pp. 3-34.

Beymer-Farris, B.A. and T.J. Bassett. 2012. The REDD menace: resurgent protectionism in Tanzania's mangrove forests. Global Environmental Change 22(2): 332-341.

Boone, C. 2003. Political topographies of the African state: territorial authority and institutional choice. Cambridge: Cambridge University Press.

Boone, C. 2007. Property and constitutional order: land tenure reform and the future of the African state. African Affairs 106(425): 557-586.

Braun, B. 2015. Futures: imagining socioecological transformation —an introduction. Annals of the Association of American Geographers 105(2): 239-243.

Burawoy, M. 1998. The extended case method. Sociological Theory 16(1): 1-33.

Cavanagh, C.J. 2018. Enclosure, dispossession, and the green economy: new contours of internal displacement in Liberia and Sierra Leone? African Geographical Review 37(2): 120-133. 
Chalfin, B. 2004. Shea butter republic: state power, global markets, and the making of an indigenous commodity. New York: Routledge.

Chalfin, B. 2010. Neoliberal frontiers: an ethnography of sovereignty in West Africa. Chicago: University of Chicago Press.

Chen, J.-C. 2013. Sustainable territories: rural dispossession, land enclosures and the construction of environmental resources in China. Human Geography 6(1): 102-118.

Cormier-Salem, M.C. 1993. Désarroi et révolte en terre de Casamance. Le monde diplomatique (February): 19.

d'Avignon, R. 2018. Shelf projects: the political life of exploration geology in Senegal. Engaging Science, Technology, and Society 4: 111-130.

Fairbairn, M. 2013. Indirect dispossession: domestic power imbalances and foreign access to land in Mozambique. Development and Change 44(2): 335-356.

Fairhead, J., M. Leach and I. Scoones. 2012. Green grabbing: a new appropriation of nature? Journal of Peasant Studies 39(2): 237-261.

Ferguson, J. 1999. Expectations of modernity: myths and meanings of urban life on the Zambian Copperbelt. Berkeley, CA: University of California Press.

Fernandez, B. 2018. Dispossession and the depletion of social reproduction. Antipode 50(1): 142-163.

Forman, G. and A. Kedar. 2004. From Arab land to 'Israel Lands': the legal dispossession of the Palestinians displaced by Israel in the wake of 1948. Environment and Planning D: Society and Space 22: 809-830.

Glaser, B.G. and A.L. Strauss. 1967. The discovery of grounded theory: strategies for qualitative research. London: Aldine.

Glassman, J. 2006. Primitive accumulation, accumulation by dispossession, accumulation by 'extra-economic' means. Progress in Human Geography 30(5): 608-625.

Goldman, M. 2005. Imperial nature: the World Bank and struggles for social justice in the age of globalization. New Haven, CT: Yale University Press.

Gordon, T. and J.R. Webber. 2008. Imperialism and resistance: Canadian mining companies in Latin America. Third World Quarterly 29(1): 63-87.

Granjou, C., J. Walker and J.F. Salazar. 2017. The politics of anticipation: on knowing and governing environmental futures. Futures 92: 5-11.

Groves, C. 2017. Emptying the future: on the environmental politics of anticipation. Futures 92: 29-38.

Hall, D. 2013. Primitive accumulation, accumulation by dispossession and the global land grab. Third World Quarterly 34(9): 1582-1604.

Hart, G. 2006. Denaturalizing dispossession: critical ethnography in the age of resurgent imperialism. Antipode 38(5): 977-1004.

Harvey, D. 2003. The new imperialism. Oxford: Oxford University Press.

Hébert, K. 2016. Chronicle of a disaster foretold: scientific risk assessment, public participation, and the politics of imperilment in Bristol Bay, Alaska. Journal of the Royal Anthropological Institute 22(S1): 108-126.

Hesseling, G. 1994. La terre, à qui est-elle? les pratiques foncières en Basse-Casamance. In Barbier-Wiesser, F.G. (ed.). Comprendre la Casamance: chronique d'une intégration contrastée. Paris: Karthala. Pp. 243262.

Holden, W., K. Nadeau and R.D. Jacobson. 2011. Exemplifying accumulation by dispossession: mining and Indigenous peoples in the Philippines. Geografiska Annaler: Series B, Human Geography 93(2): 141161.

Ince, O.U. 2014. Primitive accumulation, new enclosures, and global land grabs: a theoretical intervention. Rural Sociology 79(1): 104-131.

Kama, K. 2019. Resource-making controversies: knowledge, anticipatory politics and economization of unconventional fossil fuels. Progress in Human Geography 44(2): 333-356. 
Keating, C., C. Rasmussen and P. Rishi. 2010. The rationality of empowerment: microcredit, accumulation by dispossession, and the gendered economy. Signs: Journal of Women in Culture and Society 36(1): 153176.

Kirsch, S. 2014. Mining capitalism: the relationship between corporations and their critics. Oakland, CA: University of California Press.

Le Reste, L. 1988. Conséquences sur l'environnement aquatique et la pêche d'un barrage-écluse anti-sel en Casamance (Sénégal). In Dost, H. (ed.). Selected papers of the Dakar symposium on acid sulphate soils. Wageningen: International Institute for Land Reclamation and Improvement/ILRI. [accessed June 1 2018] http://www.documentation.ird.fr/hor/fdi:010015841.

Leitner, H. and E. Sheppard. 2018. From kampungs to condos? Contested accumulations through displacement in Jakarta. Environment and Planning A: Economy and Space 50(2): 437-456.

Levien, M. 2012. The land question: special economic zones and the political economy of dispossession in India. Journal of Peasant Studies 39(3-4): 933-969.

Levien, M. 2013. The politics of dispossession: theorizing India's 'land wars.' Politics and Society 41(3): 351394.

Li, F. 2015. Unearthing conflict: corporate mining, activism, and expertise in Peru. Durham, NC: Duke University Press.

Linares, O. 1992. Power, prayer and production: the Jola of Casamance, Senegal. Cambridge: Cambridge University Press.

Loyer, J.-Y., P. Boivin, J.-Y. Le Brusq and P. Zante. 1986. Les sols du domaine fluvio-marin de Casamance(Sénégal): évolution récente et réévaluation des contraintes majeures pour leur mise en valeur. Dakar: ORSTOM.

Lund, C. 2011. Fragmented sovereignty: land reform and dispossession in Laos. Journal of Peasant Studies 38 (4): 885-905.

Maconachie, R. 2014. Dispossession, exploitation or employment? Youth livelihoods and extractive industry investment in Sierra Leone. Futures 62: 75-82.

Makori, T. 2017. Mobilizing the past: creuseurs, precarity and the colonizing structure in the Congo Copperbelt. Africa 87(4): 780-805.

Makori, T. 2013. Abjects retraités, jeunesse piégée: récits du déclin et d'une temporalité multiple parmi les générations de la 'copperbelt' congolaise. Politique Africaine 131(3): 51.

Mamdani, M. 1996. Citizen and subject: contemporary Africa and the legacy of late colonialism. Princeton, NJ: Princeton University Press.

Manga, C.T. 2014. Les grands projects de désalinisation des sols en Casamance: entre espoir et désillusion. Revue Africaine 7.

Marx, K. 1976 [1867]. Capital. London: Pelican Books.

Mitchell, K. 2010. Pre-Black futures. Antipode 41(s1): 239-261.

Mountz, A. 2010. Seeking asylum: human smuggling and bureaucracy at the border. Minneapolis: University of Minnesota Press.

Niang, A. 2012. Mining as development? corporate/community relationships in the new gold mining sector of West Africa: the case of Sabodala, Senegal. Ph.D. dissertation. Tucson, AZ: University of Arizona.

Orozco-Quintero, A. and L. King. 2018. A cartography of dispossession: assessing spatial reorganization in state-led conservation in Saadani, Tanzania. Journal of Political Ecology 25(1): 40-63.

Perreault, T. 2013. Dispossession by accumulation? mining, water and the nature of enclosure on the Bolivian Altiplano. Antipode 45(5): 1050-1069.

Pigott, A. 2018. Imagining socioecological transformation: an analysis of the Welsh government's policy innovations and orientations to the future. Elementa: Science of the Anthropocene 6(1): 60.

Piot, C. 2010. Nostalgia for the future: West Africa after the Cold War. Chicago: The University of Chicago Press. 
Projet Grande Côte for zircon and ilmenite mining, Senegal. 2018. Environmental Justice Atlas. [accessed November 1 2019]. https://ejatlas.org/conflict/diogo-zircon-mining-niayes-senegal

Prudham, S. 2007. The fictions of autonomous invention: accumulation by dispossession, commodification and life patents in Canada. Antipode 39(3): 406-429.

Ribot, J.C. and N.L. Peluso. 2003. A theory of access. Rural Sociology 68(2): 153-81.

Rocheleau, D. and D. Edmunds. 1997. Women, men and trees: gender, power and property in forest and agrarian landscapes. World Development 25(8): 1351-1371.

Rousselin, M. 2018. A study in dispossession: the political ecology of phosphate in Tunisia. Journal of Political Ecology 25(1): 20-39.

Sabodala Gold Operations mining, Senegal. 2018. Environmental Justice Atlas. [accessed November 12019 ]. https://ejatlas.org/conflict/sabodala-gold-project-senegal

Schroeder, R.A. 1999. Shady practices: agroforestry and gender politics in The Gambia. Berkeley: University of California Press.

Simone, A. 2010. City life from Jakarta to Dakar: movements at the crossroads. London: Routledge.

Smith, B.E. 2015. Another place is possible? labor geography, spatial dispossession, and gendered resistance in central Appalachia. Annals of the Association of American Geographers 105(3): 567-182.

Smith, J.H. 2011. Tantalus in the digital age: coltan ore, temporal dispossession, and 'movement' in the eastern Democratic Republic of the Congo. American Ethnologist 38(1): 17-35.

Sneddon, C. 2007. Nature's materiality and the circuitous paths of accumulation: dispossession of freshwater fisheries in Cambodia. Antipode 39(1): 167-193.

Soederberg, S. 2013. The US debtfare state and the credit card industry: forging spaces of dispossession. Antipode 45(2): 493-512.

Sparke, M. 2007. Geopolitical fears, geoeconomic hopes, and the responsibilities of geography. Annals of the Association of American Geographers 97(2): 338-349.

Sparke, M. 2013. From global dispossession to local repossession: towards a worldly cultural geography of Occupy activism. In Johnson, N.C., R.H. Schein and J. Winders (eds.). The Wiley Blackwell companion to cultural geography. Malden, MA: Wiley. Pp. 387-408.

Sullivan, S. 2013. Banking nature? the spectacular financialisation of environmental conservation. Antipode 45(1): 198-217.

Szeman, I. 2007. System failure: oil, futurity, and the anticipation of disaster. South Atlantic Quarterly 1064(4): 805-823.

Thomson, S. 2011. Revisiting 'mandingization' in coastal Gambia and Casamance(Senegal): four approaches to ethnic change. African Studies Review 54(2): 95-121.

Weszkalnys, G. 2014. Anticipating oil: the temporal politics of a disaster yet to come. The Sociological Review 62(1_suppl): 211-235.

Zalik, A. 2015. Resource sterilization: reserve replacement, financial risk, and environmental review in Canada's tar sands. Environment and Planning A: Economy and Space 47 (12): 2446-2464. 